\title{
Rivaroxaban induced spontaneous hemoperitoneum around terminal ileum and cecum clinically mimicking acute appendicitis in a young patient: First case report
}

\author{
Ibrahim Halil Inanc ${ }^{1}$, Saadet Kılıc ${ }^{2}$, Murat Polat ${ }^{3}$ \\ 'Department of Cardiology, Besni State Hospital, \\ Adiyaman, Turkey \\ ${ }^{2}$ Department of General Surgery, Besni State Hospital, \\ Adiyaman, Turkey \\ ${ }^{3}$ Department of Radiology, Faculty of Medicine, Adnan \\ Menderes University, Aydin, Turkey
}

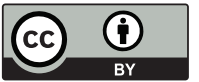

This work is licensed under

Creative Commons Attribution 4.0

International License

Received: 2020-03-23

Accepted: 2020-03-29

UDC: 616.1

\section{J Clin Med Kaz 2020; 2(56):50-52}

Corresponding Author: Dr. Ibrahim Halil Inanc, Besni State Hospital, Department of Cardiology, Adıyaman, Turkey. Tel: +90.416318 10 67, Fax: +90.416318 0773 E-mail: dr.ibrahimhalilinanc@outlook.com

\section{Abstract}

Direct oral anticoagulants have become more popular in recent years and have largely replaced vitamin $\mathrm{K}$ antagonists in the treatment of certain conditions, such as stroke prevention in atrial fibrillation and venous thromboembolism. Rivaroxaban is one of the direct oral anticoagulants that inhibit factor Xa and a rare cause of peritoneal haemorrhage which is uncommon and life-threatening complication. In this report, we present a 29 -year-old female patient using rivaroxaban due to deep vein thrombosis after pregnancy and developing intraperitoneal hemorrhage around terminal ileum and cecum clinically mimicking acute appendicitis.

Key words: rivaroxaban, intraperitoneal hemorrhage, acute appendicitis

ЖАС ПАЦИЕНТТЕ РИВАРОКСАБАНДЫ ҚОЛДАНУ СЕБЕБІНЕН ПАЙДА БОЛҒАН, АППЕНДИЦИТКЕ

ЕЛІКТЕЙТІН, МЫҚЫН ІШЕК ПЕН СОҚЫР ІШЕКТІН ТЕРМИНАЛДЫ БӨЛІМІ АЙНАЛАСЫНДАҒЫ КЕНЕТТЕН ГЕМОПЕРИТОНЕУМ

И.Х. Инанч ${ }^{1}$, С. Килич ${ }^{2}$, С. Полат ${ }^{3}$

${ }^{1}$ Кардиология бөлімі, Бесни Мемлееттік ауруханасы, Адыяман, Түркия

${ }^{2}$ Жалпы хирургия бөлімі, Бесни Мемлекеттік ауруханасы, Адыяман, Түркия

3Радиология бөлімі, Медицина факультеті, Аднан Мендерес атындағы Университет, Айдын, Түркия

\section{ТҰЖЫРЫМДАМА}

Соңғы жылдары тікелей әрекет ететін ауыз арқылы қабылданатын антикоагулянттар танымал бола бастады және жыбырлақ ырғақсыздық және веноздық тромбоэмболиямен инсульттің алдын-алу сияқты белгілі бір жағдайларды емдеуде К витаминінің антагонистері айтарлықтай алмастырылды. Ривароксабан - тікелей әсер ететін ауыз арқылы қабылданатын антикоагулянттардың бірі, ол сирек кездесетін және өмірге қауіпті.Ха факторын және ішпердеге қан кетудің сирек кездесетін себебін баяулатады. Бұл зерттеуде біз 29 жастағы науқастың жүктіліктен кейінгі терең тамыр тромбозы және ревароксабан қабылдаған және клиникалық тұрғыдан жедел аппендицитке ұқсайтын, мықын ішек пен соқыр ішек айналасында үдемелі қарыншалық қан кетуді сипаттаймыз.

Негізгі сөздер: ривароксабан, ішперде ішілік қан кету, жедел аппендицит

ВЫЗВАННЫЙ ПРИМЕНЕНИЕМ РИВАРОКСАБАНА, СПОНТАННЫЙ ГЕМОПЕРИТОНЕУМ ВОКРУГ ТЕРМИНАЛЬНОГО ОТДЕЛА ПОДВЗДОШНОЙ КИШКИ И СЛЕПОЙ КИШКИ, ИМИТИРУЮЩИЙ ОСТРЫЙ АППЕНДИЦИТ У МОЛОДОГО ПАЦИЕНТА: ПЕРВОЕ ОПИСАНИЕ КЛИНИЧЕСКОГО СЛУЧАЯ

И.Х. Инанч ${ }^{1}$, С. Килич ${ }^{2}$, С. Полат ${ }^{3}$

'Отделение кардиологии, Государственная больница Бесни, Адыяман, Турция

${ }^{2}$ Отделение общей хирургии, Государственная больница Бесни, Адыяман, Турция

${ }^{3}$ Отделение радиологии, Факультет медицины, Университет имени Аднана Мендереса, Айдын, Турция

\section{PEЗЮME}

В последние годы пероральные антикоагулянты прямого действия стали более популярными и в значительной степени заменили антагонисты витамина К при лечении определенных состояний, таких как профилактика инсульта при мерцательной аритмии и венозный тромбоэмболизм. Ривароксабан является одним из пероральных антикоагулянтов прямого действия, которые ингибируют фрактор Ха и редкую причину кровоизлияния в брюшину, которое является редким и опасным для жизни осложнением. В настоящем исследовании мы описываем 29-летнюю пациентку, принимающую ривароксабан из-за тромбоза глубоких вен после беременности и прогрессирующего внутрибрюшинного кровоизлияния вокруг терминального отдела подвздошной кишки и слепой кишки, клинически имитирующего острый аппендицит.

Ключевые слова: ривароксабан, внутрибрюшинное кровоизлияние, острый аппендицит 


\section{Introduction}

For many decades, vitamin $\mathrm{K}$ antagonists (VKAs) had been the standard anticoagulation regimen in indications of stroke prevention in atrial fibrillation (SPAF) and treatment of venous thromboembolism (VTE) [1]. Although effective, VKAs have a great number of food-drug and drug-drug interactions. Commonly co-prescribed drugs interacting with VKAs are antibiotics, diuretics and nonsteroidal anti-inflammatory drugs (NSAIDs). Foods containing moderate to high levels of vitamin K such as avocados, green peas, green tea, margarine, mayonnaise, olive oil, can reduce the effectiveness of VKA [2]. Because of variable pharmacodynamic response of warfarin, it requires routine coagulation monitoring and dose adjustment [3]. Today, direct oral anticoagulants (DOAC) are increasingly prefered over VKA because of rapid onset and offset of action, having more predictable pharmacodynamics, lower potential of fooddrug or drugdrug interactions and fewer bleeding complications [4]. Rivaroxaban is one of the most commonly used DOAC that inhibits factor Xa. Because of a potential bleeding risk as an anticoagulant, careful use is essential with respect to each individual patient [1].

In this report, we present a case of rivaroxaban associated spontaneous intraperitoneal hemorrhage mimicking acute appendicitis.

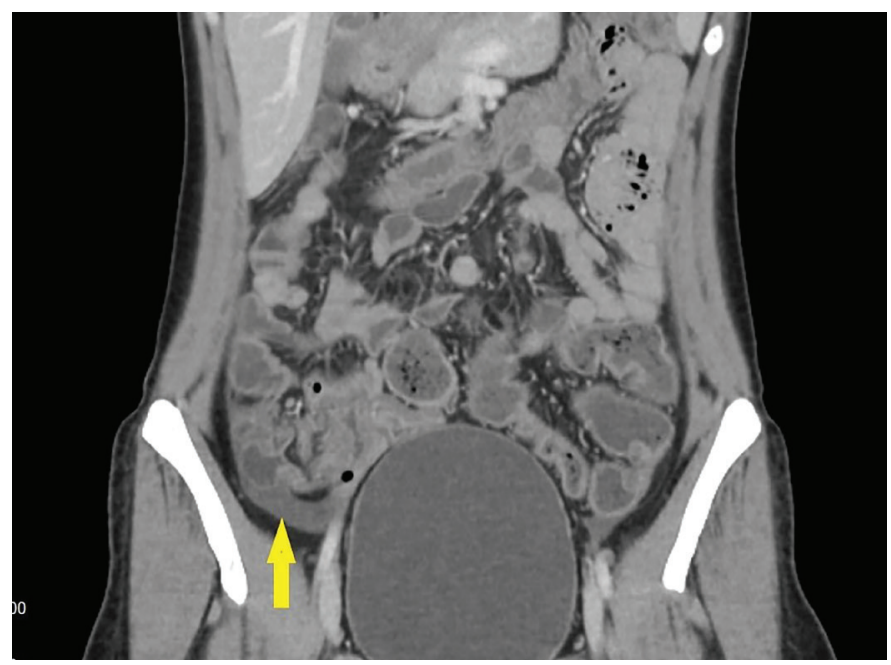

Figure 1 - Photograph of CT-scan abdomen showing pericecal fluid accumulation (arrow)

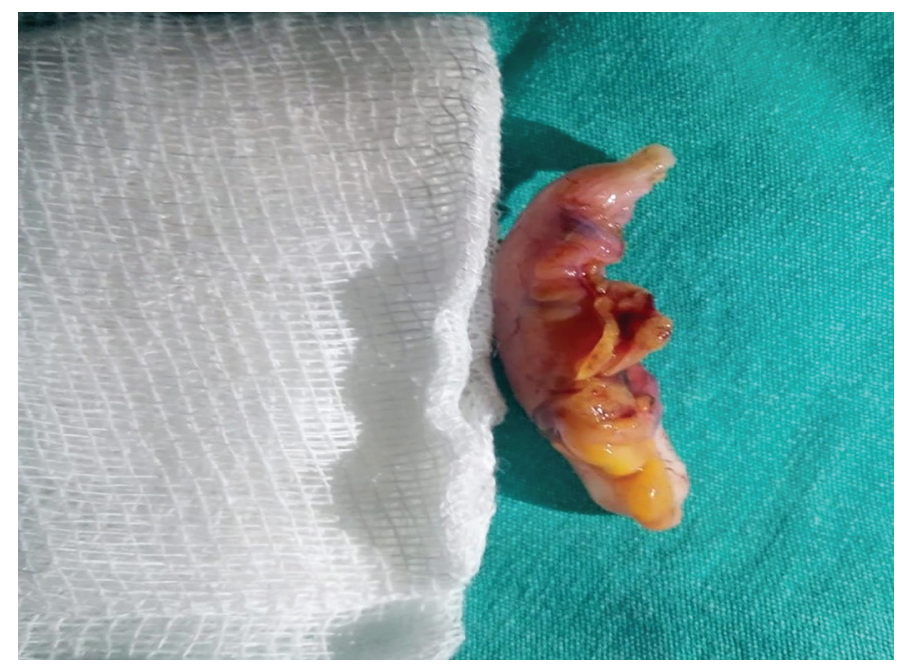

Figure 1 - Photograph of appearance of appendix

\section{Case report}

A 29-year-old woman presented to the emergency department with complaints of right lower quandrant (RLQ) pain and vomiting for 1 day. She was receiving rivaroxaban 20 $\mathrm{mg}$ once a day because the history of deep vein thrombosis after labor 3 months ago and was healthy until beginning of abdominal pain. There were no any other drugs currently used. Her body temperature was $37.5^{\circ} \mathrm{C}$, blood pressure and heart rate were normal. Physical examination revealed abdominal tenderness over the RLQ and rebound pain. The rectal examination did not reveal melena. White blood cell count (WBC) 12,700/mm3 with left shift (segment, 86.6\%; lymphocyte, 10\%), hemoglobin $11.2 \mathrm{~g} / \mathrm{dL}$ and C-reactive protein (CRP) was $60 \mathrm{mg} / \mathrm{L}$. Routine urine, electrolytes, liver function tests, lipase and amylase were all within normal limits. The X-ray film of the abdomen (kidney, ureter, bladder, KUB) showed no stones or free air. A bedside ultrasound (USG) examination revealed dilatation $(9 \mathrm{~mm})$, loss of compressibility of appendix and pericecal fluid. Abdominal computed tomography (CT) was planned to confirm diagnosis. It revealed appendiceal dilatation $(9.1 \mathrm{~mm})$, mild pericecal appendicular fat heterogeneity and pericecal fluid accumulation (Figure 1). The patient was initially treated with intravenous fluids, antibiotics, plasma products and rivaroxaban was stopped. During surgery, it was noticed that there were gross multiple spot

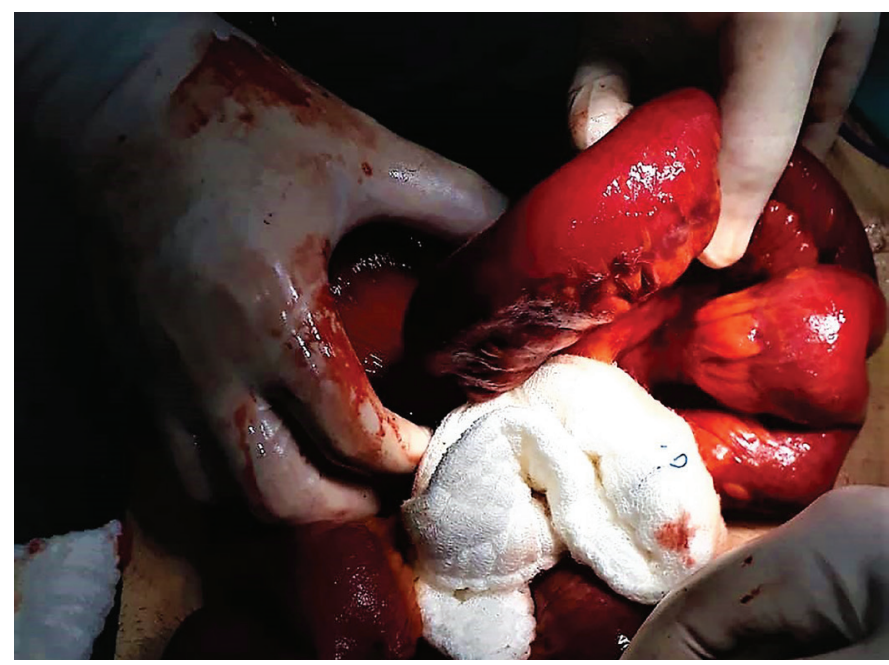

Figure 2 - Photograph of gross multiple spot bleeding areas on terminal ileum

bleeding areas on terminal ileum and pericecal blood collection (Figure 2). The appearance of appendix was normal (Figure 3). The patient was stable after discontinuation of rivaroxaban and hemoglobin level was not dropping. She was discharged 4 days after surgery.

\section{Discussion}

Rivaroxaban is commonly used as the oral Factor $\mathrm{Xa}$ inhibitor in indication of prevention and treatment of thromboembolic events. It does not require routine anticoagulant monitoring because of more predictable pharmacokinetics and pharmacodynamic profile. That is an important advantage of rivaroxaban compared to warfarin which gives convenience and satisfaction to patients and clinical physicians [5].

Although it has been shown non-inferiority of rivaroxaban versus warfarin from ROCKET-AF and EINSTEIN-DVT trials, risk of hemorrhagic complications are still a concern. The anticoagulant effect of rivaroxaban is local and/or systematic, 
so it may inhibit gastrointestinal mucosal healing. In contrast, bioavailability of warfarin is more than $95 \%$, and nonabsorbed warfarin does not have any topical effect $[4,6]$. For that reason, rivaroxaban may more likely to cause gastrointestinal bleeding (GIB).

Rivaroxaban may cause not only gastrointestinal bleeding but also intracranial, intraocular, intraarticular, retroperitoneal bleeding [1]. Isolated spontaneous intraperitoneal bleeding is rare. Clinical symptoms are related to location of blood accumulation and severity of bleeding. Sometimes it may cause spontaneous spleen rupture resulting in bleeding into peritoneal cavity [7]. In our patient it was interesting that the location of hemoperitoneum was terminal ileum. Accumulated blood around terminal ileum and cecum including peri-appendicular area probably induced local peritoneal irritation, inflammation and resulted in clinical symptoms mimicking acute appendicitis.

Although bleeding risk is higher in elderly population, young patients may also face with NOAC associated spontaneous bleeding complications. In a study, safety and efficacy of rivaroxaban being administered as a routine medication for adolescents and young adults with VTE were evaluated. Safety endpoints were defined as significant bleeding requiring any medical intervention such as: dose reduction, withdrawal of rivaroxaban or death related to therapy. Efficacy endpoints were defined as any re-VTE or thrombus progression during treatment. Patients were followed over a median period of 16 months. The bleeding incidence rate per 100 patient-years was $17.8 \%$ in fertile/premenopausal women and $4.0 \%$ in men [8].

Recently, antidote agents for DOACs have been approved by the U.S. Food and Drug Administration in indications of managing life-threatening or uncontrolled hemorrhage, but appropriate timing of administration of the antidote is important [9].

\section{Conclusion}

Since rivaroxaban is now increasingly being used, we should always keep in mind that bleeding may occur anywhere within the body and manifest with misleading symptoms even in young patients. That case demonstrates the importance of becoming aware of the potential for rare and serious bleeding complications of anticoagulants and identifying the need for early recognition and immediate management.

Disclosures: There is no conflict of interest for all authors.

Patient informed consent: obtained.

\section{References}

1. Beyer-Westendorf J, Förster K, Pannach S, Ebertz F, Gelbricht V, Thieme C, et al. Rates, management, and outcome of rivaroxaban bleeding in daily care: results from the Dresden NOAC registry. Blood, The Journal of the American Society of Hematology. 2014; 124(6):955-62. https://doi.org/10.1182/blood-2014-03-563577

2. Di Minno A, Frigerio B, Spadarella G, Ravani A, Sansaro D, Amato M, et al. Old and new oral anticoagulants: food, herbal medicines and drug interactions. Blood Reviews. 2017; 31(4):193-203. https://doi.org/10.1016/j.blre.2017.02.001

3. Mueck W, Stampfuss J, Kubitza D, Becka M. Clinical pharmacokinetic and pharmacodynamic profile of rivaroxaban. Clinical pharmacokinetics. 2014; 53(1):1-16. https://doi.org/10.1007/s40262-013-0100-7

4. Cheung K-S, Leung WK. Gastrointestinal bleeding in patients on novel oral anticoagulants: Risk, prevention and management. World journal of gastroenterology. 2017; 23(11):1954. https://doi.org/10.3748/wjg.v23.i11.1954

5. Douxfils J, Ageno W, Samama CM, Lessire S, Ten Cate H, Verhamme P, et al. Laboratory testing in patients treated with direct oral anticoagulants: a practical guide for clinicians. Journal of Thrombosis and Haemostasis. 2018; 16(2):209-19. https://doi.org/10.1111/ jth.13912

6. Investigators E. Oral rivaroxaban for symptomatic venous thromboembolism. New England Journal of Medicine. 2010; 363(26):2499510. https://doi.org/10.1056/NEJMoa1007903

7. Naseem Z, Mustaev M, Strekozov B. Spontaneous splenic rupture secondary to rivaroxaban: Rare but raising. IJSM. 2016; 2:134-6. https://doi.org/10.5455/ijsm.spleenrupture

8. Krause M, Henningsen A, Torge A, Juhl D, Junker R, Kenet G, et al. Impact of gender on safety and efficacy of Rivaroxaban in adolescents \& young adults with venous thromboembolism. Thrombosis research. 2016; 148:145-51. https://doi.org/10.1016/j. thromres.2016.09.007

9. Sherrod BA, Condie CK, Brock AA, Ledyard H, Menacho ST, Mazur MD. Emergent Reversal of Direct Oral Anticoagulants Permitting Neurosurgical Intervention for Nonhemorrhagic Pathology. World Neurosurgery. 2020; 135:38-41. https://doi.org/10.1016/j. wneu.2019.11.162

How to cite this article: Ibrahim Halil Inanc, Saadet K1lıc, Murat Polat. Rivaroxaban induced spontaneous hemoperitoneum around terminal ileum and cecum clinically mimicking acute appendicitis in a young patient: First case report. J Clin Med Kaz. 2020; 2(56):50-52 